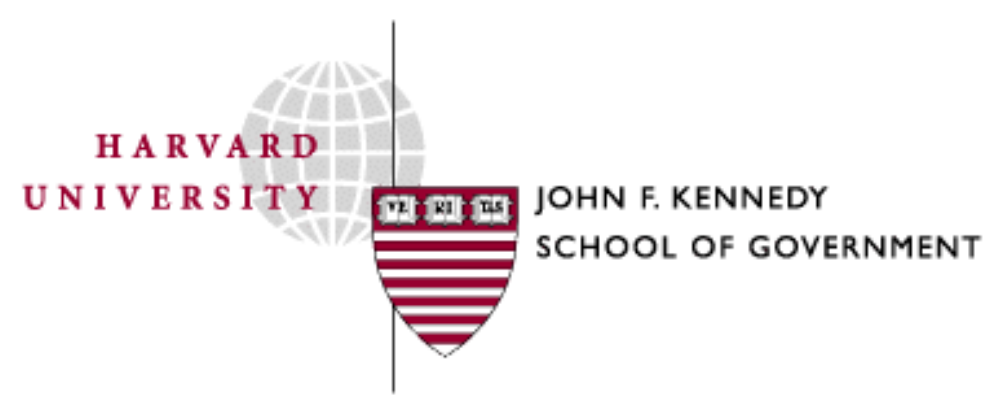

Faculty Research Working Papers Series

\title{
Seeking Asylum Alone: Treatment of Separated and Trafficked Children in Need of Refugee Protection
}

\author{
Jacqueline Bhabha
}

March 2004

RWP04-014

The views expressed in the KSG Faculty Research Working Paper Series are those of the author(s) and do not necessarily reflect those of the John F. Kennedy School of Government or Harvard University. Copyright belongs to the author(s). Papers may be downloaded for personal use only. 


\title{
Emerging Research
}

\section{Seeking Asylum Alone: Treatment of Separated and Trafficked Children in Need of Refugee Protection}

\author{
Jacqueline Bhabha*1
}

\section{INTRODUCTION}

Forced migration of refugees or trafficked persons has emerged as one of the critical human rights issues of our time. One aspect of this issue has generated increasing international political and legal concern but has not received adequate scholarly attention: how effective are the legal mechanisms that seek to protect child asylum seekers who are separated from their families because of persecution or trafficking? This question underpins a new, international research project being launched at Harvard University in conjunction with the University of Sydney in Australia and collaborators in the United Kingdom and the Netherlands. Preliminary research has already been started in Germany, Austria, Sweden, and Norway.

Children have always constituted a significant proportion of the international refugee population. The largest number of child refugees travel as members of families forced to flee persecution (they constitute at least $50 \%$ of the refugee population). A smaller number are unaccompanied refugee minors, abandoned or orphaned in refugee camps or war zones (they constitute $2 \%$ to $5 \%$ of camp populations). But, apart from the distinct episodes of the exodus of the 14,000 Pedro Pan Cuban children in the early 1960s and the Vietnamese boat children in the mid-1970s, separated ${ }^{2}$ children trafficked or travelling on their own to seek asylum in distant countries have received scant scholarly attention. Systematic

\footnotetext{
* John F. Kennedy School of Government, Harvard University, Cambridge, MA, USA.
} 
research on the efficacy of asylum as a mechanism for protecting separated children simply does not exist.

\section{SEPARATED CHILD ASYLUM SEEKERS: A KEY POLITICAL ISSUE}

Yet, the distinctive problems facing separated child asylum seekers are at the heart of asylum policy discussions in several states and regions, including the United States, Australia, and the European Union (EU). There are at least two reasons why this is the case. First, their numbers have escalated dramatically over the last decade, to the point where separated children now constitute at least 4 per cent of the asylum seeking population in many destination states. In some states they constitute more than 15 per cent of asylum seekers (UNHCR, 2002). In Australia in mid-2001 the number of children arriving on some boats accounted for as many as 30 per cent of the total number of arrivals; many were unaccompanied. ${ }^{3}$ In the United States approximately 5,000 separated children are detained by immigration authorities every year (Women's Commission for Refugee Women and Children, 2002). According to the Separated Children in Europe Project (SCE), a joint initiative of the International Save the Children Alliance and the United Nations High Commissioner for Refugees, there are at least 25,000 separated children at any given time in Europe.

Second, the problem of separated child asylum seekers is a key political issue because of mounting concern about child trafficking. There is growing evidence of the involvement of traffickers in a significant minority of child asylum cases (Nugent and Schulman, 2001). Among some nationalities it has become clear that children's search for asylum is facilitated by exploitative and abusive arrangements, both during and after the journey (Bhabha, 2000; IOM, 2002). It also appears that traffickers are encouraging abuse of the asylum procedure. For example, some trafficking networks threaten their young charges with draconian punishment if they refuse to use fabricated stories in their asylum applications (IOM, 2002; Nugent and Schulman, 2001). Strong policy arguments can therefore be advanced for studying the legal protections available to this population.

\section{RETHINKING "CHILD-SPECIFIC PERSECUTION"}

Apart from providing a rigorous profile of this problem, the inquiry will contribute to a broader set of theoretical questions. First, granting asylum constitutes one of the most powerful and successful contemporary human rights remedies; yet available evidence (often anecdotal) suggests that separated children find it 
much more difficult than adults to gain asylum. They have difficulties getting adequate legal representation, their cases are more likely to be postponed and to drag on over time, and they have less chance of being granted refugee status. The outcome of an asylum application is often a troubling limbo of indeterminacy, rather than a reassuring guarantee of a permanent status (Amnesty International, 1999; Ruxton, 2000; Women's Commission for Refugee Women and Children, 2002). For example, according to estimates by Save the Children (UK) only 1 or 2 per cent of separated child asylum seekers receive full refugee status; the majority receives a humanitarian or exceptional "leave to remain", a discretionary immigration status which can be withdrawn after a child is age 18. The central question is whether these children, burdened by the double jeopardy of alienage and minority, are discriminated against in the asylum process. If minority is a handicap rather than an advantage in securing human rights protection, how and why is this so? Is it because separated child asylum seekers have less valid asylum claims? Given the increasingly restrictive and adversarial climate surrounding asylum in destination states, why is it that a growing number of children are travelling alone to seek protection? Is it because of the changing impact of war and ethnic strife on civilians, the dislocation of families by increased globalization, the impact of child trafficking? Are families choosing to send their children alone to seek asylum, or are children deciding to set off on their own to escape persecution?

Second, the refugee protection regime derives its legal force and international legitimacy from the 1951 United Nations Convention Relating to the Status of Refugees (as amended by the 1967 Protocol). This international human rights treaty, as translated into domestic law, is the starting point for all non-citizens seeking asylum. Although age neutral on its face, some argue that there is a normative assumption that refugees are adults. Children are treated differently rather than equally. Threats facing child asylum seekers (as political activists in their own right or as members of targeted families) are ignored or trivialized. Child-specific forms of persecution - such as child abuse, child selling, or child trafficking - are not considered to fall within the ambit of the five "grounds" for protection: race, religion, nationality, membership of a particular social group, and political opinion. Thus, according to the SCE project, when considering whether a child has a valid ground for fleeing his or her country of origin, responsible officials often pay insufficient attention to children's circumstances.

There are virtually no examples ... of cases where child-specific forms of human rights violations are taken into consideration in the refugee status determination. There is considerable evidence that some countries enrol children in armies or rebel groups, but there is often official disbelief that the problem exists. For example, in the Netherlands, a child who claims to be afraid of forced recruitment into the army is sometimes considered as no more than a draft dodger (Ruxton, 2000). 
The most straightforward explanation advanced is that, as in other areas of international law, children have tended to be invisible, their issues minimized by an adult-centred focus (Sadoway, 1997). A somewhat different interpretation is that child asylum seekers, like street children in some countries, are not ignored but excluded, targets of social hostility, fear, and exclusionary measures rather than of protective concern (Bhabha, 2001), "runaways or throwaways" as a key US juvenile immigration official once described them in conversation with me. Save the Children (UK) notes the pervasive suspicion that dominates decision making in this field - according to a cited source, "the younger you are, the more suspicious they are around you" (Save the Children, 2002). This study will test these interpretative frameworks against the data collected. We will ask whether equality rather than difference is a more effective basis for securing protection.

The key question that the project will investigate is the following: how well has the Refugee Convention worked for children who are not included in family applications but seek asylum in their own right? The project will investigate whether child specific persecution is being recognized or conversely ignored as a basis for the grant of asylum. It will also inquire whether this is a result of the approach of immigration/asylum officers, advocates, or adjudicators/judges. The project will identify different categories of children seeking protection (children fleeing war or other threats similar to those that force adult asylum seekers to flee, children fleeing child specific persecution, children who are trafficked as part of a trade in sexual or other services). The project will also collect data on separated child asylum seekers accorded protection on humanitarian grounds rather than as refugees.

\section{GOALS OF RESEARCH PROJECT}

This project is intended to provide the first detailed theoretical and empirical study of the impact of asylum on separated children. It has three specific objectives. The first is a research objective - the compilation of systematic data, both quantitative and qualitative, on the topic for the first time (this data set will be of use to other researchers and policy analysts). The second is a set of policy objectives. These include recommendations about substantive and procedural aspects of child asylum protection for national and international bodies (to be the subject of a report and subsequent briefing meetings), and - following a successful similar initiative relating to gender persecution - the development of a web site of innovative legal precedents (briefs, judgments, legal arguments) to assist advocates in developing new advocacy strategies within their own jurisdiction. Third, I hope that we will make a theoretical contribution to the under- 
standing of children's agency as rights bearers, and more generally to the literature on forced migration, trafficking, and children.

\section{METHODS OF INVESTIGATION}

Research will be carried out in the United States, the United Kingdom, and Australia, three countries where separated and trafficked child asylum seekers are a key political concern, but where little systematic information exists. ${ }^{4}$ The study will include a comparative analysis of the international and domestic legal frameworks available to deal with separated children, an analysis of the relevant case law, and a literature survey. This analysis will situate the phenomenon of child migration within the broader picture of forced migration today, including consideration of the increasingly restrictive and adversarial climate for refugee protection in destination states.

Research will be conducted to attempt to collect and analyse decisions on asylum applications, their antecedents, and the aftermath for trafficked and separated children arriving between January 1999 and December 2002 in each of the three countries. The publication of decisions about asylum cases is erratic and incomplete. Most asylum cases are decided at administrative or legal levels where there is no precedent value and no reporting obligation. They are, therefore, relatively inaccessible. In some jurisdictions (e.g. Canada) only negative decisions are supported by written reasons, unless the case is taken to a higher court. While this dearth of information about outcomes affects all asylum applications, it may be particularly acute in children's cases where access to legal representation and due process protections seem to be especially hard to secure. It is likely (though there is no conclusive information on this) that only a small proportion of children's asylum cases are the subject of formal legal proceedings. The research will collect as much information about child asylum cases as possible. In each country surveyed, the study seeks to establish, for the period covered, what proportion of child asylum applicants are successful and how this figure compares with the success rate for adults. The research will also attempt to gauge processing times. Are significant numbers of child asylum applications undecided for long periods of time? Are children being refused asylum or other legal status, and if so what happens to them? Are the children legally represented? If so, are they represented by experienced advocates or by trainees or law students; are they represented by lawyers who take instructions directly from the child client or lawyers who act primarily for others, e.g. smuggling networks? Are children allocated a guardian, a designated representative, or some other adult adviser who mentors and guides them through the legal process, and has a "best interest" approach or child care expertise? If 
not, how do children secure suitable assistance? (In a recent US case, a oneand-a-half year old appeared unrepresented at the first asylum court hearing). The project will only include trafficked and separated children who enter the asylum process at some stage in their migration. Of course many children who are trafficked or in refugee-like situations will thus be excluded from the research; children may not surface in the asylum system due to lack of knowledge or access, or because other forms of protection and welfare are available, or because they choose to remain undocumented to avoid the risk of exposure or expulsion. These children may be as deserving of asylum as those within the asylum system. But to track them down would require a research project on a different scale from that envisaged here.

The project will explore how the asylum adjudication system within a given country maps its international obligations onto its domestic decisions. It will analyse the meaning and application of the "best interests of the child" principle as it applies to both the process and the outcome of the asylum determination system. It will examine how the populations of trafficked and separated child asylum applicants compare between different countries, in terms of nationality of origin, age and gender distribution, and nature of claims. It will examine the discrepancies in the application of the different legal statuses between countries; it will compare levels of legal protection and, conversely, frequency of removal or deportation of children in the different countries and whether specially designed programmes of return have been established. Selected children's asylum hearings will be observed, and separated children's detention centres/shelters will be visited.

\section{CONCLUSION}

Research will include the collection of all available statistical data, both published and by request to immigration, asylum, and judicial authorities (either by simple request or, in the United States and Australia, through a Freedom of Information Act application if necessary). It will also include analysis and classification of all reported cases, and diligent efforts to collect information on unreported cases from newsletters, telephone surveys, or interviews with relevant adjudicators/judges, advocates, welfare agencies, academics, law firms, government officials, refugee, anti-trafficking and children's rights nongovernmental organizations (NGOs), community groups, international organizations, and other entities. Where available, child asylum seekers will be interviewed about their experience in the asylum determination system. Copies of relevant documents used in children's claims (briefs/applications submitted, case outlines of successful claims, background document submissions or witness 
statements, judges' orders) will be collected. Due care will be taken to assure the anonymity of the child respondents and the information collected about their experiences and protection outcomes. The results of the research will be contributed to a database of decisions on child asylum cases (with precedents and sample pleadings). Roll out meetings with policy makers, NGOs, and advocates are envisaged as part of the dissemination of the findings in future.

This project is intended to be the first part of a broader study eventually encompassing ten other countries, including Canada, the Netherlands, Germany, France, Austria, Spain, Italy, Hungary, Sweden, and South Africa. Support for this broader project will be sought from international organizations (including UNHCR and UNICEF) and foundations. I hope in due course scholars and NGO or freelance researchers from the countries listed will collaborate in the broader project. A steering board of key advisors/experts will oversee the work of the project.

\section{NOTES}

1. The author welcomes feedback from readers, particularly those with knowledge of relevant cases, information, or suggestions. Please email Jacqueline Bhabha at Jacqueline_Bhabha@harvard.edu or my Australian collaborator Mary Crock at maryc@law.usyd.edu.au

2. I use the adjective "separated" rather than the traditional term "unaccompanied" to include children who, though accompanied, are not in the company of a parent or of a legal or customary caregiver. They could, for example, be with a trafficker, a sibling, or a family acquaintance. Thus, we follow the UNHCR definition of a separated child.

3. These figures are obtained by doing manual calculations of the figures given in relation to individual boat arrivals in the Department of Immigration and Multicultural and Indigenous Affairs, Fact Sheet No 74A, available at www.immi.gov.au/ facts74A.html.

4. In the United States, there has been vociferous public concern over the treatment of separated children by the immigration authorities which includes the extensive use of detention and the conflict of interest inherent in the former Immigration and Naturalization Service (INS) having both enforcement and protective responsibility for these children; this has resulted in the recent decision, enacted in the controversial Homeland Security Act, to transfer custody of separated children from the former INS to the Office of Refugee Resettlement. In the United Kingdom, there has been heated public controversy over government statements that asylum seeking children are "swamping" public schools and should be removed to special institutions; in Australia, the use of isolated and punitive detention facilities to house separated child asylum seekers has been sharply criticized, a key reason why the main facility, the notorious Woomera Detention Centre, has been closed down. 


\section{REFERENCES}

Amnesty International

1999 Most Vulnerable of All: The Treatment of Unaccompanied Refugee Children in the UK, Amnesty International, London.

Bhabha, J.

2000 "Lone travelers: rights, criminalization, and the transnational migration of unaccompanied children", University of Chicago Law School Roundtable, 7:269-294.

2001 "Minors or aliens? Inconsistent state intervention and separated child asylum-seekers", European Journal of Migration and Law, 3.

International Organization for Migration (IOM)

2000 Migrant Trafficking and Human Smuggling in Europe, IOM, Geneva.

2002 Journeys of Jeopardy: A Review of Research on Trafficking in Women and Children in Europe, no. 11, IOM, Geneva.

Nugent, C., and S. Schulman

2001 "Giving voice to the vulnerable: on representing detained immigrant and refugee children", Interpreter Releases, 78(39), 8 October.

Ruxton, S.

2000 Separated Children Seeking Asylum in Europe: A Programme for Action, Save the Children, Stockholm.

Sadoway, G.

1997 "Refugee children before the immigration and refugee board", Immigration Law Reporter, 35.

Save the Children

2002 Cold Comfort: Young Separated Refugees in England, Save the Children, London.

UNHCR

2002 Number of Asylum Applications Submitted by Unaccompanied or Separated Children, UNHCR, Geneva, 27 September.

Women's Commission for Refugee Women and Children

2002 Prison Guard or Parent?: INS Treatment of Unaccompanied Refugee Children, Women's Commission for Refugee Women and Children, Washington, DC, May. 